Versión “postprint” del documento publicado en:

García López, Sonia. Filling the voids of memory: alzheimer's disease and recent history in Nedar and Bucarest, la memòria perduda . Catalan Journal of Communication \& Cultural Studies Vol.6, N.1, pp. 19-33

(C) Intellect 


\section{Filling the voids of memory: alzheimer's disease and recent history in Nedar and Bucarest, la memòria perduda}

\begin{abstract}
After the Franco dictatorship, the politics of the past in Spain became a problematic issue. The work of mourning those defeated during the Spanish Civil War had to be postponed during Francoism and recovered during the transition to democracy, a process marked by intense public debates on the history and memory of the Spanish Civil War. During the course of the last decade, the grandchildren of the combatants started to literally unearth the dead and tried to recover their memory. The Catalan documentaries made in 2008, Nedar (Carla Subirana) and Bucarest, la memòria perduda (Albert Solé), give Alzheimer's disease a key role in the storytelling of the recent past. This article deals with the representation of that disease, understood as a metaphor for the forgetting of history, and the historical and theoretical implica-tions derived from the use of fiction and archival images as means of filling the voids of memory.
\end{abstract}

Keywords

Alzheimer's disease documentary Francoism historical memory politics of the past Spanish Civil War 
1. The master class was part of the parallel activities of the International

Documentary Film Festival

Documenta Madrid 2011.
Remember how to forget.

(Honig 2010)

Human episodic memory is a means by which selves are related to history and to the particularity of circumstance. This process is creative, original and constructive and not always subject to the constraints of realism.

(Scheibe 1989)

\section{CINEMA AND THE DISCOURSES ON THE PAST}

In a master class given at the Círculo de Bellas Artes of Madrid in $2011{ }^{1}$ the Hungarian director Péter Forgács spoke about whether it is possible for a documentary film-maker working with archival images to recover 'the present and/or the past (...) our just happening, existing life in reality' (Forgács 2011). Somehow, Forgács was concerned about how to recover experience in its phenomenological dimension: life as it was felt at the time it was being filmed and, thus, embalmed, by an amateur - or an anonymous - film-maker trying to obtain filmed records of family life. The answer was complex, and involved understanding such a historical approach as a uchronic zone (that is, a place out of time, for past time, by definition, cannot be recovered). Forgács also raised the question about the way in which the permanent flood of media representations conditions human perception of time and, specifically, of past time understood as 'hard-boiled' fact. After all, Forgács asked rhetorically, 'Are there ways to be in dialogue with the past other than the cliché [sic] media forms?' (Forgács 2011).

The questions outlined by Forgács in his lecture are not only of primary importance for any reflection on the relationship between history and documentary film (both from a practical and from a theoretical point of view), but they are also very symptomatic of the current concerns of documentary filmmakers approaching the representation of the past, collective memory and personal memory. The notion of the archive and the need to keep records of everyday experience, as well as of public events, have become crucial at a time when the proliferation of media productions has reached its highest peak, thanks both to the democratization of media producing and recording technologies, and to the development of the Internet as a new and alter-native kind of screen, as opposed to the traditional unidirectional means of media delivery. Paradoxically, as media records of public and private life are proliferating and reaching ever larger audiences, concerns about the human inability to endure and narratives centred on the need to fix both personal and historic memory have become increasingly present in the western hemisphere. The clichés and representational patterns established by time-based media (from TV to YouTube, as well as more ephemeral forms of audio-visual communication such as Skype) contribute to shaping our perception of the present and the past and, from this point of view, affect the way in which we deal with the representation of memory, especially when a specific historical context is approached.

From this point of view, the aim of this article is to address documentary films made by contemporary film-makers, dealing both with the representation of the past and with the current concern with the failure of memory to recover the past in its experiential dimension, in order to discuss the way in which the politics of the recent Spanish past are approached from a personal 
point of view in these films. By doing so, I aspire to strengthen the idea that the representation of Alzheimer's disease in documentaries whose stories go beyond the personal approach to reach the representation of the past including historical events - epitomizes some of the current ways of deal-ing with the failure of technology to fulfil the old dream of human beings, as conceptualized by André Bazin, of 'embalming time' (1960), despite the invention and improvement of time-based media such as cinema and video.

These are times of obsession with memory. Traumatic events such as World War II, the Nazi camps, the bombing of Hiroshima and Nagasaki, the Spanish Civil War and the Franco regime, crimes and genocides committed by this and other dictatorships in the last mid-century, or the 9-11 terrorist attacks, taught us about the need to articulate a series of devices on collective memory to prevent any recurrence of such traumatic events (Ruiz Torres 2007: 7-8). Film and media culture, understood as a primary source of the history of the twentieth century and as a key element of private history, is a privileged means for the representation of memory. In the documentary field, which is the focus of this article, films as different and distant in time as Alfred Hitchcock's Memories of the Camps (1945), Alain Resnais's Guernica (1950) and Nuit et Brouillard (1955), Claude Lanzmann's Shoah (1985), Patricio Guzmán's Chile, la memoria obstinada (1996-1997), the Private Hungary series by Péter Forgács (Privát Magyarország, 1988-2008) or Susana de Sousa's 48 (2009) deal with the need to come to terms with a traumatic past considering the specific circumstances characterizing each era or time (implying different ways to come to terms with the traumatic past).

In most cases, these discourses on the past arise as a challenge to 'official memory', which, in repressive regimes, usually aims to legitimize traumatic moments of history through a biased understanding of their past and contemporary time (Juliá 2006). In Spain, for instance, Francoist newsreels produced by No-Do aimed, from their very beginning, to articulate a discourse on the past as a means of legitimizing an ideal of the nation that was being highly contested abroad - and stigmatized inside the borders - due to the dramatic experience of the Civil War (Rodríguez Tranche and Sánchez-Biosca 2001, 2011).

Reacting to the 'official memory' of fascisms and Nazism, as well as to the acts of retaliation by the Allies in Dresden, Hiroshima and Nagasaki, documentaries made after World War II in France, the United Kingdom or the United States resorted to the so-called 'pedagogy of horror', which used shock tactics as a cathartic way of bringing the audience face-to-face with images of barbarism (Sánchez-Biosca 2006a: 143). By the 1980s a new way of addressing memory emerged. It conceded a great deal of importance to the word of the witness and displaced the focus from collective to individual experience, via the work of mourning and melancholia, ${ }^{2}$ as evidenced by the work of Claude Lanzmann and Patricio Guzmán. ${ }^{3}$ Individual storytelling still works here as a paradigm of the collective, contributing to the refusal of official memories, not through an exemplary discrediting based on archive footage and organized by an omniscient storyteller but through the understanding of individual, exemplary stories told by those who stand as witnesses.

The gradual 'personalization of memory' that arises in these documenta-ries offering alternative projects to the official memory has become hegemonic during the last twenty years to the point of becoming one of the gravitational forces of contemporary documentary. Nonetheless, the film-maker plays an increasingly less frequent role as an intermediary between the witnesses of
2. I refer here to the concepts of mourning and melancholia, as theorized by Freud in his key essay 'Mourning and Melancholia' (1917).

3. In this regard, a study on Lanzmann's work can be found in $\mathrm{M}$. Renov (2004: 120-30) and V. Sánchez-Biosca (2006a: 87-39). Regarding Patricio Guzmán's work, see J. Peris Blanes (20022003: 65-82). 
4. The word 'subject' is understood here both as the grammatical function performing the action referred to and as the person being discussed, described or represented in the documentary. This dyadic approach to the 'subject' of

documentary was introduced by Michael Renov (2004).

5. Even if lacking historical ambition and an auto-reflexive dimension, so powerfully present in Forgacs's works, the documentary by José Luis López-Linares and Javier Rioyo Un instant en vida aliena (2003) also starts from the recovery of a private film archive, Madronita Andreu Klein's, to depict the daily life

of the Catalan high bourgeoisie during a part of the twentieth century.

6. It is an alternative memory in the sense that it relates to private lives rather than to the great historical events that are recounted in official records.

7. Although the impact of this 'obsession with memory' in the media goes beyond the aims of this article, it is important to bear in mind that we also find a great deal of films dealing with the spectre of losing memory or identity among the most commercial productions. Just to mention a few: Abre los ojos/Open your eyes (Amenábar, 1997) and its remake Vanilla Sky (Crowe, 2001); Memento (Nolan, 2000); The Final Cut (Naïm, 2004);

Eternal Sunshine of the Spotless Mind (Gondry, 2004); Fifty First Dates (Segal, 2004); The Bourne Series (The Bourne Identity, Liman, 2002; The Bourne historical and traumatic events and the audience, in order to stand himself or herself as the 'subject' of the documentary. ${ }^{4}$ In the works of contemporary directors such as Alan Berliner (Intimate Stranger, 1991; Nobody's Business, 1996), Ross McElwee (Sherman's March, 1986; Bright Leaves, 2003) or Lech Kowalski (East of Paradise, 2005), history remains in the background of the storytelling, becoming meaningful only to the extent to which it overlaps with the director's personal history, which is often told in terms of a search for his or her personal identity. In these and other documentaries, such as those studied in this article, the collective issue has been displaced to a secondary level, while the question of individual identity has gained unexpected prominence in the documentary context.

Moreover, due to the recovery of private films made by anonymous individuals, we are witnessing a kind of 'archive fever' in its domestic dimension. We are witnessing a proliferation of stories dealing with historical memory issues that are addressed from an individual or private standpoint, clearing the way for narratives dealing with (historical) memory from a more or less individual or private point of view. Such is the case in the works of Péter Forgács', which make up the Private Hungary series (1988-2008), or in his film El perro negro: Stories from the Spanish Civil War (2006), which recovers footage corresponding to the Spanish II Republic and the Civil War, filmed by Joan Salvans' family and by the amateur film-maker Ernesto Díaz Noriega. ${ }^{5}$

In short, whether we are dealing with documentaries in which the historical references are intimately linked to the film-maker's personal identity, or with others that take as their starting point a private and anonymous recording of the past as a means of offering an 'alternative memory' differing from the offi-cial one, ${ }^{6}$ personal memory, understood as a key element for the inception of identity, is becoming more and more important in the development of historiography and cinematic discourses on the past. The visibility of this concept in the media $^{7}$ - and both in the academic ${ }^{8}$ and the political milieu - is such that we might even speak of memory 'saturation' or even of 'abuses of memory', as, for instance, Tzvetan Todorov (2000) does. In this context, the collective dimension of individual memory is being progressively diluted, to the point of investing terms and converting the historical discourse about the past - either in its official versions or in the alternative ones - into a sort of implant needed to articulate individual identity, which is increasingly perceived as something labile and undefined.

\section{THE FILM-MAKER AS AN ARCHAEOLOGIST OF TIME}

Even if they understand the introduction of the personal, the individual and the private at the core of the discourse on the historical past in different ways, Forgács and Berliner share an anthropological approach to cinema. The filmmaker is seen, in this regard, as an archaeologist for whom the archival image is seen not so much as a rough document containing some truth about the past but more as a starting point that, beyond its unquestionable value as a document, requires an analytic approach, an interpretative one, with which the film-maker's gaze needs to be engaged (Forgács 2011). The Private Hungary series consists of fifteen documentaries centred on the ominous years of World War II, marked by massive deportations, concentration camps and the extermination of millions of human beings, and focuses in particular on the Hungarian holocaust through amateur films and home movies shot in Hungary by people who, like Zoltán Bartos and his family or Captain Nándor 
Andrásovits, suffered or witnessed the repression led by the Nazi authorities. ${ }^{9}$ Beyond their value as precious traces of private life in Central Europe during that crucial period, these private films, secret in many cases, are Forgács' starting material. Moreover, the fundamental value of this film-maker's work goes beyond bringing to public view these films made originally for domestic consumption, since they serve to point out, comment on and resituate the major events that shook the world and undoubtedly convulsed everyday life, bursting violently into the private sphere and disintegrating family life. As a matter of fact, Forgács's archaeological approach to archival footage recalls Michel Foucault's ideas about the way in which history, as a discipline, approaches the document:

Now, through a mutation that is not of very recent origin, but which has still not come to an end, history has altered its position in relation to the document: it has taken as its primary task, not the interpretation of the document, nor the attempt to decide whether it is telling the truth or what is its expressive value, but to work on it from within and to develop it: history now organizes the document, divides it up, distributes it, orders it, arranges it in levels, establishes series, distinguishes between what is relevant and what is not, discovers elements, defines unities, describes relations.

([1969] 2002: 7)

Meanwhile, Berliner develops his archaeological labour by portraying his family universe, digging into the origins of his ancestors to discover, sometimes against the wishes of his loved ones, a past marked by victimization, exile and displacement brought about by traumatic historical events. His desire to restore the family memory and situate it in a historical setting plays a key role when the film-maker says:

Home movies are lies. Home movies are idealized false representations of the family. Smiley-faced postcards for posterity. If someone from another planet were to learn about life on earth solely from looking at a few rolls of old home movies, they would be led to believe that every day was a Sunday, that every month was August, that every season was summer. That life on earth was one big party - a place of leisure without struggle. Now let me tell you a few things I love about home movies. Home movies are anthropological sites. Shards from archaeological digs. They are mirrors. They are windows. Time capsules. They are questions waiting to be answered. They are answers waiting to be questioned.

(Berliner 2004)

The latest projects to date of the New York film-maker, Translating Edwin Honig. A Poet's Alzheimer's (2010) and First Cousin Once Removed (2012), seem to carry the operation proposed in previous films such as Intimate Stranger (1991) - devoted to his maternal grandfather - and Nobody's Business (1996) with the director's father as the main character - to a wider, self-reflexive dimension. Indeed, Berliner's recent documentaries deal, once again from the family domain, with what has become one of the great obsessions of our time: the loss of memory, in a literal sense, and the loss of self-identity attached to that process: in other words, Alzheimer's disease, which, in this case, is suffered by Berliner's first cousin, the great poet and translator Edwin Honig.
Supremacy, Greengrass, 2004; The Bourne Ultimatum, Grengrass, 2007; The Bourne Legacy, Gilroy, 2012); Unknown (Brand, 2006); Black Mirror: 'The Entire History of You' (Welsh and Broker, 2011).

8. See Todorov (2000). Regarding this question in the specific context of Film Studies, see V. Sánchez-Biosca (2006b) and V. J. Benet (2007).

9. I have studied Péter Forgács work in an earlier essay (2011). 
10. First Cousin Once Removed was released in the International Documentary Film Festival Punto de Vista of Navarra on

21 February 2013. The following quotations are from personal notes taken during the presentation by Alan Berliner.

11. Words pronounced by the director during the presentation of the film at Punto de Vista Festival Internacional de Cine Documental de Navarra, 2013 edition.

12. An early documentary dealing with Alzheimer's disease, not from a medical point of view but from a personal one, was Complaints of a Dutiful Daughter (Hoffmann 1994).

13. In 1998, four years after Ronald Reagan was diagnosed with Alzheimer's disease, PBS produced a documentary that traced the life and political story of the president from the teleological perspective of his disease (Hoyt 1998). In 2011 Reagan's son published a book claiming that his father exhibited symptoms of Alzheimer's while in office (Reagan 2011), and a documentary by US director

Eugene Jarecki (2011) contradicted him, giving way to a debate on the subject (Solomon 2011).

14. The Iron Lady (Lloyd 2011).

15. Bicicleta, cullera, poma/ Bicicleta, cuchara, manzb
During the presentation of First Cousin Once Removed in its Spanish release, ${ }^{10}$ Alan Berliner talked about the relationship between this film and his previous works, which, in fact, place a great deal of importance on the link between personal and family memory, and social history, as a means of representation of individual identity. The films about Edwin Honig are 'an attempt to understand and think about memory, forgetting, life and death' from a very close experience in which the film-maker stands, at the same time, close and distant from his subject. The direct link between Berliner's first cousin's experience with Alzheimer's disease and the reflection on the film-maker's own identity was expressed by Berliner when he said about the film: 'It changed my perception about memory. It enabled me to imagine a future in which I may not be able to remember that I was here, that I made a film, that I was a film-maker'. ${ }^{11}$

\section{REMEMBER TO FORGET}

Among other reasons, I am particularly interested in Translating Edwin Honig and First Cousin because, with these documentaries, Berliner establishes a bridging point between the anthropological approach to self-identity based on domestic footage and a broader reflection on memory and identity, and therefore connects - from an international point of view - to the topic discussed in this article within the Spanish context: the increasing interest in Alzheimer's disease as related to family background and the historical past. This disease, which was discovered by the neurologist Alois Alzheimer in 1906, has generated a growing interest outside the domain of neuronal medicine and experimen-tal or physiological psychology studies in recent decades (Scheibe 1989). Both K. E. Scheibe (1989) and J. F. Ballenger (2006) consider that, coinciding with the moment in which, by the 1980s, 'computer analogies have demonstrated the necessity of employing memory in a functional sense [...], and memory is here to stay as a central topic in psychology' (Scheibe 1989: 141), Alzheimer's disease became increasingly associated with the terrifying prospect of losing one's self. ${ }^{12}$ Both authors approach the study of Alzheimer's disease from a Human Science perspective, assuming that the relations between history, memory, identity and narrative cannot be avoided in the understanding of this disease. Moreover, the relationship between personal memory (especially the episodic kind) and history is key to understanding the way in which self-iden-tity is constructed (and fades with Alzheimer's disease). Thus, in recent years this cultural and historical approach to the study of Alzheimer's has entered public discourse in a variety of disciplines and contexts of the cultural sphere, giving rise to the visibility of the illness in the media and enabling a meta-phorical potential, generated when the disease is suffered by political person-alities. Well-known cases supporting this idea are those of Ronald Reagan (Reagan 1998) ${ }^{13}$ and Margaret Thatcher (object of a biopic in which her illness is alluded to) ${ }^{14}$ or, in the Spanish context, Adolfo Suárez (first Prime Minister of the postFranco democracy), or Pasqual Maragall (prominent Socialist Party politician and mayor of Barcelona during the Olympic Games 1992), who also has been the subject of a documentary. ${ }^{15}$

In 2008 two documentaries dealing with history and memory were made in Catalonia: Bucarest, la memòria perduda, by Albert Solé, and Nedar, by Carla Subirana. The films were very different in nature but, even allowing for their differences with Forgács's and Berliner's examples discussed above, both of them coincided in addressing the historical past of Spain starting from a 
personal approach to their family stories. ${ }^{16}$ More specifically, they did so by documenting the deterioration produced by Alzheimer's disease in close relatives who, due to their age or because of their participation in key historical events, had an ability to bear witness, which the illness took from them.

Interestingly enough, Albert Solé's film uses clichéd images and discourses from the media to fill the voids of memory, thus establishing a significant link between Spain's recent past, the director's father's fading memory, and Albert Solé's final opportunity to put together the dispersed clues that would enable him understand his past as a child and clear the enigma of his personal identity, blurred by hiding and exile.

In turn, Subirana refuses to draw on footage, and brings into play fictional and creative strategies in order to shape the lost memories of her grandmother, or even things that never happened or whose witnesses are gone, but whose imagining is understood as a key element in overcoming the trauma provoked both by historical and family events and by the appearance of Alzheimer's disease.

The historical juncture and the narratives adopted by these documentaries for the representation of memory tell us about the ways in which contemporary Spanish documentary explores the relationship between history and memory, a matter that, as we will see, has colonized the social imaginary during the first decade of this century.

\section{Bucarest, la memòria perduda}

Bucarest, la memòria perduda/Bucharest. Lost Memory tells the story of Jordi Solé Tura, another prominent politician - along with Adolfo Suárez and Pasqual Maragall, from the transitional period to democracy in Spain. As outlined above, the story is told from the point of view of his son, Albert Solé, for whom the personal memories of his father hold the key to his identity, veiled for long periods of exile and underground life while he was a child. The words opening the documentary are illustrative of the above-mentioned idea:

My father's memories are fading and, with them, the answers to so many questions about origins; his and mine. [...] As a child, I used to believe that I was French; when I was six, they told me I was Hungarian [...]. One day, my parents gave me a new script. I was nine [...]. I started to mistrust this new twist in history. I was going crazy: Where was I really born ${ }^{17}$

Undoubtedly, these are questions about personal identity that no history book would ever be able to answer. And yet they are inextricably linked, in this story, to the political destiny of the country. To recover, or rather to fix, personal and family memory, Albert Solé set about rebuilding the increasingly weak memories of his father, a historic fighter against the Franco dictatorship from exile (and then underground in Spain itself) who became one of the 'Fathers of the Constitution' during the transition to democracy. The way in which Solé approaches the reconstruction of his father's memory is remarkably interesting, since his task does not draw upon his father's testimony, nor brings into play familiar footage, but, instead, it leans on the testimonies of Jordi Sole's wife and ex-wife (Albert Sole's mother) and, most importantly, on interviews with prominent politicians and intellectuals. In addition, Solé borrows archival footage from historical documentaries and news reports.
16. Furthermore, the archaeological metaphor on cinematic discourses about the past acquires a material expression in documentaries dealing with the opening of mass graves and the recollection of vestiges from the victims of the Francoist repression, which started in 2000 as an initiative of the Asociación para la Recuperación de la Memoria Histórica founded by Emilio Silva and Santiago Macías: Así en la tierra como en el cielo (Alonso and Guardia 2002), and Les fosses del silenci (Armengou and Belis 2003).
Los recuerdos de mi padre se desvanecen, y con ellos, las respuestas a tantas incógnitas sobre los orígenes; los suyos y los míos. [...] De pequeño siempre creí que era francés. Un día, a los seis años, me explicaron que era húngaro [...]. Un día mis padres me volvieron a cambiar el guión. Tenía nueve años. [...] Empezaba a desconfiar de ese nuevo giro en mi historia. me estaban volviendo loco. ¿Dónde había nacido yo realmente?

(00:02:42-00:03:56) 
This strategy is undoubtedly coherent with the narrative development of Albert Solé's family story, marked by exile and clandestine living, since these situations are not likely to produce (due to the restrictive conditions of underground life) any kind of recorded material, legitimating thus the utilization of official records.

However, this narrative strategy is, at the same time, ambivalent, since the personal, individual memory of Jordi Solé that his son is trying to save from oblivion in order to solve the enigma of his own identity is being displaced by collective memory, understood here as 'a narrative representation, so to speak, a story about the past which is hold by a group and which, regarding the members integrating it, goes beyond the horizon of individual memory' (Ruiz 2007: 28).

Interestingly, Bucarest is not about private, family memories, but about an eminently public memory legitimated by a number of authoritative sources and eyewitnesses. This documentary, entirely conventional from the point of view of narrative structure and style, focuses on the last years of the Franco regime and the democratic transition. As if responding negatively to the above-mentioned question by Forgács, 'Are there ways to be in dialogue with the past other than the cliché media forms?', Bucarest reconstructs the recent history of Spain using a vast archive of film and media sources among which are included some of the most well-known archival images on the country's history during the twentieth century. As explained above, in most cases we are not talking about private or domestic footage but about footage coming from newsreels and documentaries, images that, mostly, were fixed in the retina of the Spanish people and became legendary or acquired great iconic value. This is the case, for instance, of the footage corresponding to the announcement of Franco's death by Carlos Arias Navarro through TVE, or to Dolores Ibarruri La Pasionaria's return from exile.

Furthermore, following the codes of classical historical documentary, the film-maker draws on the technique of 'talking heads' in the form of interviews with political personalities and eyewitnesses such as Jorge Semprún, or Santiago Carrillo, who have an important presence within the documentary. In turn, the voice-over ranges between nostalgia and a distanced - even ironic - tone, preventing the film-maker from falling into melodramatic codes: it moves in a delicate balance between the public and the private that often recalls the pattern established by television series like The Wonder Years (Black and Marlens 1988-1993) or the Spanish Cuéntame cómo pasó (Crespi and Cano 2001-). In spite of the personal and family frame in which the story is inscribed, the narrator (Albert Sole himself) also links his memories with the 'atmosphere' being felt in Spain during those years in which his father played a prominent role in politics. Thus, we can hear from the narrator's mouth a series of clichéd expressions, which could scarcely be described as informa-tive, borrowed from those used frequently in the media such as 'el régimen daba sus últimos coletazos'/'the regime was on its last legs', 'recuerdo la sensación de aire fresco, las manifestaciones'/'I remember the feeling of fresh air, the demonstrations' or 'volvieron los exiliados; era el fin del silencio, de la clandestinidad'/'the exiles came back - silence, underground life, had ended'. These personal memories, whose formulation is borrowed from stereotyped sentences established as clichés by the media during the Transition and, especially, once democracy had been consolidated, are far from the last strongholds of memory of the director's father, for they are shaped out of the public discourses on the Spanish recent past as displayed in the media. Notwithstanding, this way to proceed can be understood as a figurative strategy 
illustrating how the social dimension of individual memory, described by María Inés Mudrovcic (Ruiz Torres 2007: 28) as the individual memory socially mediated, and the memory inscribed into the body through social practices (the so-called habitus, to use Bourdieu's conceptualization), takes shape. ${ }^{18}$

If, as Pedro Ruiz Torres asserts (2007: 33), memory and oblivion have a lot to do with either the maintenance or the loss of links with the group with which the individual shares memories, in Bucarest, the construction and enhancement of a group narrative based on a shared experience of repression and exile stand at the core of the possibility, searched by the director, of safeguarding his father's personal memory and his own identity. From this point of view, the social dimension of individual memory stands in Bucarest as a resistance device when personal memories start to fade. Therefore, although Solé paradoxically used public records, and only a few private ones, to articu-late the story of the recovery of his personal identity, the director emphasizes the importance of the value of personal memory, even making a statement about its purity, when his mother also suffers a stroke:

I hardly understand why family memories persist in disappearing. This time it was my mother's, she was the only guardian that had preserved intact the memories of my childhood. ${ }^{19}$

In short, Bucarest, la memòria perduda articulates an ambivalent story about the relationship between the historical past and personal identity, showing the problematic and often contradictory dynamic between these two concepts, so frequently invoked to discuss memory from a social point of view. Consciously or not, in this film, personal and family memory are configured as mythic spaces where memories are safeguarded, allowing the subject to recognize himself as an individual and as a member of a community. At the same time, images that have become icons and clichés coded by the media give shape to that personal story in its struggle to overcome the destructive power of time represented by Alzheimer's disease.

\section{Nedar}

With Nedar, Subirana goes back a little further into the past to explore the memory of the Spanish Civil War through a family, a personal and a subjec-tive prism, but one radically different from Albert Solé's, as we shall see. Like Bucarest, Subirana's film also deals with the traumatic experience of Alzheimer's disease, which is suffered first by her grandmother and then by her mother afterwards. From the present time, marked by the unstoppable advance of the disease and the spectre of the loss of the director's own memory, due to the genetic roots of the illness, Nedar plunges into the past to try to find out the truth about the fate of Juan Arroniz, Subirana's grandfather, shot dead in 1940 by Franco's army in unresolved circumstances. From this point of view, Subirana's Nedar brings into play a self-reflexive and self-representational approach to reality. The documentary shows the very process of film produc-tion through time, including the director's research about Juan Arroniz, Subirana's 'creativity crisis' - solved in part thanks to the encounters with her mentor Joaquim Jordà, which are also part of the film, and her assistance to the mental deterioration of both her grandmother and mother.

Like in Bucarest, the film goes far beyond portraying the diverse phases of the
18. On the other hand, as Ruiz Torres (2007: 31) pointed out according to Halbwachs, when the individual remembers, he or she does so with the means provided by the society in which he or she lives (particularly, the language). Therefore, the group memory (the family collective memory, the religious collective memory, the traditions of different social classes, among other group's memories) is expressed and takes place in the individual memory.

19. 'Me cuesta entender porqué la memoria familiar se obstina tanto en desaparecer. Esta vez, le ha tocado a mi madre, la única guardiana intacta de los recuerdos de mi infancia.

(00:53:27-00-53-3 8 , emphasis added) 
advancing illness, which plays a key role in two ways: first, it functions as an engine driving the director to rush and ask questions to her mother and her grandmother, before their memory about her grandfather's fate ultimately fades away; second, Alzheimer's disease plays a major role in Subirana's quest about her own identity, both from an individual point of view (confronting the possibility of 'inheriting' the disease), from a family point of view (as the granddaughter of a defeated individual who later on was convicted by the Francoist dictatorship) and from a social point of view (inscribing her story within a collective dimension through cinematic representation).

In any case, all similarities with Bucarest stop here. As it has been pointed out, for Nedar Subirana did not draw upon found footage. By using only images shot for the documentary itself (including interviews, dramatizations and even a kind of picture-novel) and private movies filmed by the director over many years, the film interweaves the story of Subirana's investigation of the real causes of her grandfather's death, on the one hand, and the dete-rioration of family memories, embodied by the director's grandmother and mother, on the other. As Laura Gómez Vaquero remarked,

the short interview with her grandmother [...] gives evidence of the elderly woman's failure to provide any significant information to the investigation but, at the same time, impulses and justifies the search itself: as the director explains during the film, 'while my grandfather was taking shape in my imagination, my grandmother was fading away [...] she was walking away from us'.

(Gómez Vaquero 2009: 114)

Furthermore, the staging of the research process in the development of the film allows the director to show the skeleton of the narrative, the structure on which the story of the family's memory retrieval stands: not only do the doubts and uncertainty about the true nature of the facts emerge constantly, but in addition the film also reflects on the best way to recount them, sharing with the audience the discursive nature of memory and the creative, imagina-tive flair lying behind the act of storytelling, both with regard to history and to our personal memories, as Paul Ricoeur has taught us (2004). For Ricoeur, history and fiction are not antagonistic categories, but complementary. In other words, the historical cannot be told without resorting to fictional, narra-tive devices. At the same time, fiction, throughout temporal configuration, makes the human experience meaningful and reveals how it materializes. For him, history, even in its lesser narrative form, is linked to narrative under-standing through an indirect bypass, thanks to which historical knowledge comes from the narrative understanding without losing its scientific char-acter. In other words, for Ricoeur the reference to a real past must be done in terms of re-figuration - that is, in a hermeneutical key, and here imagi-nation plays a key role. From this point of view, the film-maker's utilization of fiction to draw her grandfather's, Juan Arroniz, story is coherent, for it is presented as an honest, straightforward story. It is thus depicted as it was moulded in Subirana's imagination after her research and access to reports, data and disconnected family stories. Breaking with the rules of conventional documentary, the past emerges here as fiction, as black and white pictures looking like something out of a photo-novel or a film noir, but which were filmed specifically for the documentary with professional actors.

Since the fictional nature of the staging of some moments of Juan Arroniz's life is 
explicit through the above-mentioned cinematic devices, it is up to the spectator to draw the separating line between research and romance. In any case, the feeling that Subirana is closer to the truth than at the beginning of the film invades the viewer's conscience, along with the certainty that the ability to imagine has played an important role in the understanding of her family past, the origins of her personal identity. When the investigation comes to an end, we find that the knowledge about her grandfather acquired by the filmmaker has involved a learning process about storytelling itself, about how memory works and how it is structured by our mind in order to remember, and this is a key element in resolving the fear of loss of memory that hovers over the entire film. All this leads to an ending in which the film-maker frees herself of many of the fears and anxieties unleashed by her grandmother's and mother's illness, partially displacing the spectator's attention to new charac-ters that were missing before: her partner and her newborn son, a new family thanks to which the story looks to the future on the basis of the resolution, during the process of film-making, of the enigmas of the past.

\section{CONCLUSION}

Bucarest and Nedar are narrative projects that - while very different from one another - aspire to 'fill the voids of memory' brought about by Alzheimer's disease. Also, significantly enough, these films seek to reveal something that does not have much to do with historic and collective memory, but with their director's individual identity. Solé uses stereotyped film and media footage, while Subirana stays within the confines of the personal and draws upon creative re-enactment, or even fictional devices, assuming that the absolute actualization of memory is impossible and that there is always an imaginative act behind the work of remembrance, as pointed out by Scheibe (1989: 152).

Significantly, these very personal visions of the recent, and not so recent, Spanish past, produced in 2008, were made with institutional support (Televisió Espanyola and Televisió de Catalunya in the first case; Televisió de Catalunya and Memorial Democràtic in the second), and emerged in the context of a heated debate over historical memory in Spain. The year 2006 had been proclaimed the 'Year of Historical Memory' by one of the most controversial bills of Zapatero's first term, which elicited very different assessments from the major newspapers. At the centre of the controversy was the 'Law of recognition and extension of rights to victims of the civil war and the dictatorship', known in the media as 'Law of Historical Memory', which aimed to 'recognize and extend the rights of and establish measures for those who suffered persecution or violence during the Civil War and the dictatorship'. As Jo Labanyi (2008) points out, the law was the subject of much controversy in the media, and conservative newspapers such as $E I$ Mundo and $A B C$ expressed their shared regret that the government had disturbed the ghosts of the past and opened up the can of worms of historical memory. As a bizarre example of this 'memory fever', Labanyi refers to the:

'Obituary war' that followed the publication in the national press, on 17 July 2006, of a death notice for the first Republican officer shot by the rebel troops, submitted by his daughter on the grounds that obit-uary for Republican victims had been banned during the dictatorship; this provoked a flurry of such notices commemorating other victims 'vilmente asesinados por las hordas rojas', countered by further notices on the Left, until the hostilities petered out in 2007. 
20. The awareness of the ephemeral nature of time as one of the main features of the Modern Era, as conceptualized by Karl Marx in The Communist Manifesto ([1848] 2012), and its implications on the self, have

been re-elaborated from a theoretical, historical and cultural perspective by a variety of authors, such as

M. Berman (1982),
According to historian Ruiz Torres (2012), the emergence of the 'recovery of the memory of civil war', understood as a means of rehabilitation of victims of war and dictatorship in Spain, had been intense and growing since 2000, both in civil society and in the political arena and the media. It was then that groups like the Association for the Recovery of Historical Memory (founded by Emilio Silva and Santiago Macias in 2000) began to appear:

As well as television documentaries, widely distributed books, often written by journalists, novels on 'discovered' events and people, politi-cal prisoners sent to concentration camps, forced labour, women and men executed for their struggle against the dictatorship ... All accom-panied at the political level since 2000 by a law of historical memory in some regional parliaments.

(Ruiz Torres 2012: 5)

Beyond the desire for revenge or the political demand for the memory of the vanquished during the Civil War, which for many decades was only kept alive by exiles, many of these initiatives aimed to bring to an end the work of mourn-ing needed to heal the wounds caused by war that still remained open, as evidenced by the virulence that these issues released into the public sphere, more than 70 years after the conflict had ended. Supporting the search for the bodies of missing people, helping relatives to recover and identify them and give them a proper burial, was the purpose of the Association for the Recovery of Historical Memory, a purpose that has been echoed in documentaries like Asi en la tierra como en el cielo/On Earth as in Heaven (Alonso and Guardia 2002).

The documentaries that I have discussed here, Bucarest, la memòria perduda and Nedar, share in and contribute to this atmosphere saturated with stories about the recent Spanish past, distant yet intensely present in the twenty-first century. The directors of both documentaries belong to the second post-civil-war generation - namely, the grandchildren of those who were involved in it. Their way of interrogating the past is radically different from that characteristic of previous generations: they are not interested in finding an anchor in mythical times to legitimize a national project or an ideal for the future, nor in impeaching official memory to accommodate, from their personal experience, an alternative memory project in order to question the previous model. It has to do, above all, with exorcising one of the great fears of our time: the inability to endure.

Even if both documentaries start from a personal approach, they are also of historic importance, and this is what interests us, for these two examples are representative of the way in which we understand history at the present time, characterized by the consumer society and the fragility of memories subjected to the accelerated flow in which our daily experience takes place: a time marked by a liquid and ephemeral reality that threatens memory, and ultimately, the ability to endure. ${ }^{20}$ Moreover, these discourses emerge at a time when the concepts of subjective and collective identity are perceived as unstable categories, as Peter and Christa Bürger pointed out (2001). This, to some extent, explains the appeal (and the anxieties) aroused by the question of the fragility of memory in recent years.

\section{ACKNOWLEDGEMENTS}

The author would like to express her gratitude to Vicente Rodríguez Ortega for reading and reviewing the final version of this article. 


\section{REFERENCES}

Anon. (2005), 'La familia de Adolfo Suárez habla por primera vez de su enfermedad: "No recuerda que fue presidente"'/,'Adolfo Suárez's family speaks about his illness for the first time: “He doesn't remember that he was a President"' El Mundo, 31 May, http://www.elmundo.es/ elmundo/2005/05/31/espana/1117574199.html. Accessed 25 February 2013.

Alonso, E., and Guardia, I. (2002), Así en la tierra como en el cielo/On Earth as in Heaven, València: Otrapeliculaesposible.

Armengou, M. and Belis, R. (2003), Les fosses del silenci/The Spanish Holocaust, Barcelona: Televisió de Catalunya (TV3).

Ballenger, J. F. (2006), Self Senility, and Alzheimer's Disease in Modern America: A History, Baltimore: The Johns Hopkins University Press.

Bazin, A. (1960), 'Ontology of the photographic image', Film Quarterly, 13: 4, pp. 4-9, Summer.

Benet, V. J. (2007), 'Excesos de memoria: El testimonio de la Guerra Civil española y su articulación fílmica', Hispanic Revue, 75: 4, pp. 349-363

(Philadelphia: University of Pennsylvania Press).

Berliner, A. (1991), Intimate Stranger, New York: Alan Berliner.

- - (1996), Nobody's Business, New York: Alan Berliner.

- - (2004), 'Like my father before me', lecture given at New York University,

7 May, http://dspace.unav.es/dspace/bitstream/10171/18495/1/Berliner\%20 -Like\%20my\%20father\%20before\%20me\%20\%28web\%29.pdf. Accessed 25 February 2013.

(2010), Translating Edwin Honig: A Poet's Alzheimer's, New York: Alan Berliner.

- - (2012), First Cousin Once Removed, New York: Alan Berliner for Experiments in Time, Light \& Motion and HBO Enterprises.

Berman, M. (1983), All That Is Solid Melts Into Air: The Experience of Modernity, New York: Verso.

Black, C. and Marlens, N. (1988-1993), The Wonder Years, USA: New World Television/The Black/Marlens Company.

Bosch, C. (2010), Bicicleta, cullera, poma/Bicycle, Spoon, Apple, Barcelona: Televisió de Catalunya/TVE/XTVL.

Bürger, Ch. and Bürger, P. (2001), La desaparición del sujeto. Una historia de la subjetividad de Montaigne a Blanchot/The Disappearance of the Subject: A History of Subjectivity from Montaigne to Blanchot.

Crespi, A. and Cano, A. (2001-), Cuéntame cómo pasó/ Remember When, Madrid: Grupo Ganga / TVE.

De Sousa Dias, S. (2009), 48, Lisboa: Kintop.

Doane, M. A. (2002), The Emergence of Cinematic Time: Modernity, Contingency, the Archive, Harvard: Harvard University Press.

Forgács, P. (1988-2008), Privát Magyarország/Private Hungary, Budapest: For-Creation.

-- (2006), El Perro Negro: Stories from the Spanish Civil War, Budapest: For-Creation.

- - (2011), 'Archaeology of time or alternative memories', Documenta Madrid 11 Catalogue, Madrid: Festival Internacional de Documentales Documenta Madrid, http://www.documentamadrid.com/documentamadrid11/paralelas.php?cod_seccion=119. Accessed 25 February 2013.

Freud, S. (1917), 'Mourning and melancholia', The Standard Edition of the Complete Psychological Works of Sigmund Freud, Vol. 14, pp. 23960 (London: The Hogarth Press). 
Foucault, M. ([1969] 2002), The Archaeology of Knowledge, Abingdon: Routledge. García López, S. (2011), 'Restos diurnos. Péter Forgács y la ensoñación histórica'/'Day's Residues. Péter Forgács and the historical reveries', Blogs\&Docs. Revista online dedicada a la no ficción, 4 July, http://www. blogsandocs.com/?p=835. Accessed 25 February 2013.

Gómez Vaquero, L. (2009), 'Hacer visible el trauma. La invocación de la memoria en la producción documental desde los años sesenta en España'/'Visualizing the trauma: The invocation of memory in the documentary from the 1960's in Spain', Secuencias. Revista de historia del cine, 30: 1, pp. 153-156 (Madrid: Universidad Autónoma de Madrid).

Guzmán, P. (1996-1997), Chile, la memoria obstinada/Chile, the Obstinate Memory, Paris/Santiago/Ottawa: La Sept-Arte/Les Films d'Ici/National Film Board of Canada (NFB).

Hessens, R. and Resnais, A. (1950), Guernica, Paris: Panthéon Productions.

Hitchcock, A. (1945), Memories of the Camps, London: Ministry of Information/ London's Imperial War's Museum (released in 1985 under the title: $A$ Painful Reminder: Memory of the Camps).

Hoffmann, D. (1994), Complaints of a Dutiful Daughter, New York: Women Make Movies.

Hoyt, A. (1998), Reagan, Arlington: PBS.

Juliá, S. (ed.) (2006), Memoria de la guerra y del franquismo/Memory of the

Spanish Civil War and Francoism, Madrid: Taurus.

Kowalski, L. (2005), East of Paradise, Paris, Extinkt Films.

Labanyi, J. (2008), 'Introduction', The Politics of Memory in Contemporary Spain, Journal of Spanish Cultural Studies, 9: 2, pp. 119-125.

Lanzmann, C. (1985), Shoah, Paris: Historia/Les Films Aleph/Ministère de la

Culture de la Republique Française.

Lloyd, P. (2011), The Iron Lady, Paris and London: Pathé/Film4.

López-Linares, J. L., and Rioyo, J. (2003), Un instant en vida aliena/A Moment

in Someone Else's Life, Barcelona: Cero en Conducta/Fresdeval Films. Marx, K. and Engels, F. ([1848] 2012), The Communist Manifesto, London: Verso. McElwee, R. (1986), Sherman's March, New York: Home Made Movies Inc.-- (2003), Bright Leaves, New York: Home Made Movies Inc.

Peris Blanes, J. (2002-2003), 'El archivo y el tiempo de la subjetividad. La memoria obstinada de Patricio Guzmán'/'The archive and the time of the

subjectivity: Patricio Guzmán's Chile, the Obstinate Memory', Estudios:

revista de investigaciones literarias, 20-21, pp. 65-82.

Reagan, R. (1998), 'Alzheimer's letter', http://www.pbs.org/wgbh/americanexperience/features/primary-resources/reagan-alzheimers/. Accessed 25 February 2012.

Reagan, R. Jr (2011), My Father at 100: A Memoir, London and New York: Penguin Books.

Renov, M. (2004), The Subject of Documentary, Minneapolis/London:

University of Minnesota Press.

Resnais, A. (1955), Nuit et brouillard/Night and Fog, Paris: Argos Films. Ricoeur, P. (2004), Tiempo y narración I. Configuración del tiempo en el relato histórico/Time and Narrative I, México: Siglo XXI.

Rodríguez Tranche, R. and Sánchez-Biosca, V. (2001), NO-DO. El tiempo y la memoria/NO-DO: Time and Memory, Madrid: Cátedra/Filmoteca Española. - - (2011), El pasado es el destino. Propaganda y cine del bando nacional en la Guerra Civil/The Past is Fate: Propaganda and Cinema on the Francoist Side During the Spanish Civil War, Madrid: Cátedra/Filmoteca Española. 
Ruiz Torres, P. (2007), 'De perplejidades y confusiones a propósito de nues-

tras memorias'/'The perplexities and confusions about our memories', HISPANIA NOVA. Revista de Historia contemporánea, 7: 1, pp. 1-30.

- - (2012), 'Los discursos de la memoria histórica en España'/'The discour-

ses of historical memory in Spain', in J. Peris Blanes (ed.), Debates de la memoria en España y nuevas investigaciones en torno a la violencia

franquista, Buenos Aires: RIERH, pp. 3-29.

Sánchez-Biosca, V. (2006a), Cine de historia, cine de memoria. La representación y sus límites/Film history, Film Memory: Representation and its Boundaries, Madrid:

Cátedra.

- - (2006b), Cine y guerra civil española. Del mito a la memoria/Cinema and the

Spanish Civil War: From Myth to Memory', Madrid: Alianza.

Scheibe, K. E. (1989), 'Memory, identity, history and the understanding of dementia', in L. E. Thomas (ed.), Research on Adulthood and Aging: The Human Science Approach, Albany: State University of New York Press, pp. 141-159.

Solé, A. (2008), Bucarest. la memòria perduda/Bucharest: Lost Memory, Barcelona: Bausan Films/Minimal Films/Televisió de Catalunya (TV3)/Televisión Española (TVE).

Solomon, D. (2011), 'Questions for Eugene Jarecki: The Reagan Evolution', The New York Times, 4 February, http://www.nytimes.com/2011/02/06/ magazine/06FOB-Q4-t.html. Accessed 25 February 2013.

Subirana, C. (2008), Nedar/Swimming, Barcelona: Benecé Produccions/Televisió de Catalunya (TV3).

Todorov, T. (2000), Los abusos de la memoria/The Abuses of Memory, Barcelona: Paidós.

\section{SUGGESTED CITATION}

García López, S. (2014), 'Filling the voids of memory: Alzheimer's disease and recent history in Nedar and Bucarest, la memòria perduda', Catalan Journal of Communication \& Cultural Studies 6: 1, pp. 19-33, doi: 10.1386/

cjcs.6.1.19_1

\section{CONTRIBUTOR DETAILS}

Sonia García López is a visiting professor of Cinema and Media Studies at Universidad Carlos III of Madrid and author of the books Spain is US. La guerra civil española en el cine del Popular Front (1936-1939) (València, PUV, 2013) and Ser o no ser. Ernst Lubitsch (Barcelona, Paidós, 2005). She is also the co-editor, with Laura Gómez Vaquero, of the collective volume Piedra, papel y tijera: el collage en el cine documental (Ocho y $1 / 2 /$ Textos Documenta, 2009). She is a regular contributor to the journal Secuencias. Revista de historia del cine, and worked for seven years as Editorial Board Assistant at Archivos de la Filmoteca. Revista de estudios sobre la imagen, published by the Valencian Film Institute.

Contact: Universidad Carlos III de Madrid, Facultad de Humanidades, Comunicación y Documentación, C/Madrid 133, 28903, Getafe, Madrid.

E-mail: sogarcia@hum.uc3m.es 